\title{
WIZJA EDUKACJI GLOBALNEJ NA PRZYKLADZIE INICJATYW EDUKACYJNYCH W AUSTRALIJSKICH SZKOŁACH
}

Streszczenie: W artykule została omówiona problematyka edukacji globalnej w Australii. Została ona scharakteryzowana $\mathrm{z}$ uwzględnieniem celu i miejsca w australijskim programie edukacji. Charakterystyka edukacji globalnej w Australii została przygotowana w oparciu o założenia, które są uwzględnione australijskim programie edukacji, Deklaracji Melbournskiej oraz w międzyprzedmiotowych celach edukacyjnych. Ponadto zaprezentowano wybrane działania edukacyjne realizowane w szkołach australijskich, spełniające założenia edukacji globalnej.

Słowa kluczowe: edukacja globalna, Australia, zrównoważony rozwój, program kształcenia.

\section{Wstęp}

Problematyka edukacji globalnej w polskiej literaturze podejmowana jest stosunkowo często. Autorzy przy charakterystyce tego rodzaju edukacji skupiają się szczególnie na dwóch aspektach. Pierwszym jest dokonanie opisu, wytłumaczenie jej specyfiki oraz priorytetów (Babicki, Kuleta-Hulboj 2016; Bińczak 2013; Karpińska 2003; Kojs 2002; Kucińska 2009; Łomny 1996, 1998; Szymański 2001; Wojnar 200o). Drugim, w szczególności, opis rozwiązań bądź działań podejmowanych w ramach jej założeń (Gadzinowska 2008; Gadzinowska i in. 2012; Hechmann, Bodzan 2014; Horton, Klus-Stańska 1994; Kędzierska-Grasiewicz 2001; Kołodko 2001; Noszczyk 2011; Nowaczyk, Świderek 2012; Ocetkiewicz 2014; Rosa 2000; Szczygieł i in. 2013; Trzaskowski i in. 2013).

Przyjmując jako punkt odniesienia definicję edukacji globalnej sformułowaną w Deklaracji z Maastricht w sprawie edukacji globalnej (2003), „Edukacja globalna otwiera ludziom oczy i umysły na świat oraz uświadamia im konieczność podejmowania działań na rzecz upowszechnienia sprawiedliwości, równości i praw człowieka dla wszystkich. Edukacja globalna jako globalny wymiar edukacji 
obywatelskiej obejmuje edukację rozwojową, edukację o prawach człowieka, edukację na rzecz zrównoważonego rozwoju, edukację na rzecz pokoju i zapobiegania konfliktom oraz edukację międzykulturową" (Global Education Network Europe 2009, s. 16), dostrzec można, że wskazuje ona na potrzebę podejmowania działań na wielu poziomach, tym samym umożliwiając instytucjom czy jednostkom jak najwłaściwszy dobór działań do kluczowych w danym momencie potrzeb.

Aby dokonać w sposób możliwie wyczerpujący opisu działań związanych z edukacją globalną oraz zaprezentować konkretne działania edukacyjne odnoszące się do priorytetów w tym zakresie, należy uwzględnić podstawy, w oparciu o które ten rodzaj edukacji jest realizowany właśnie w Australii.

Australia ze względu na swoją historię oraz obecną politykę podchodzi bardzo poważnie do działań związanych z edukacją globalną. Realizuje się ją w związku $\mathrm{z}$ założeniami zawartymi $\mathrm{w}$ trzech istotnych dokumentach. Pierwszym jest Australijski Program Nauczania (Australian Curriculum), drugim - Deklaracja Melbournska (Melbourne Declaration on Education Goals for Young Australians), a trzecim międzyprzedmiotowe priorytety nauczania (Cross-curriculum priorities).

Australia, będąc krajem niemającym najbliższych sąsiadów ze względu na swoją historię i politykę, jest mocno zaangażowana w kwestie edukacji, z uwzględnieniem jej globalnego charakteru. Do głównych obszarów edukacji globalnej w australijskim wydaniu zaliczyć można: kształtowanie lepszej wspólnej przyszłości dla świata; jedności i współzależności społeczeństwa; rozwijanie poczucia siebie; uznawanie różnorodności kulturowej; afirmację sprawiedliwości społecznej i praw człowieka oraz budowanie pokoju i działań na rzecz zrównoważonej przyszłości w różnym miejscu i czasie. Zatem edukacja globalna, w rozumieniu australijskim, promuje pozytywne wartości i pomaga uczniom brać odpowiedzialność za swoje działania i postrzegać siebie jako globalnych obywateli, którzy mogą przyczynić się do funkcjonowania bardziej pokojowego, sprawiedliwego i zrównoważonego świata.

Do głównych przyczyn tak dużego zaangażowania Australijczyków w kwestię edukacji globalnej, zaliczyć można fakt że Australia jest krajem imigrantów, zatem hasła takie jak np. uznawanie różnorodności kulturowej w wypadku tego kraju stają się nie tylko teorią czy ewentualnością na wypadek potrzeby sprostania potrzebie edukacji przybyszów, lecz przybierają jak najbardziej konkretne formy. Wszakże w australijskiej szkole obecność dziecka, które przyjechało z innego kraju, ma rodziców z innego kraju czy nie mówi po angielsku, jest normą. W szkołach realizowany jest nawet narodowy program pt. English as an Additional Language (ACARA, 2013), który zakłada obecność odpowiednio wyszkolonego nauczyciela w klasie. Jego rola skupia się na przygotowaniu „nowego Australijczyka”, do nauki języka angielskiego i nauki właściwego funkcjonowania w szkole. Przykładem jednoznacznie ukazującym traktowanie edukacji globalnej jako celu priorytetowego może być fakt, że założenia tego rodzaju edukacji zostały uwzględnione w Australijskim Programie Nauczania (Australian Curriculum). 


\section{Australijski Program Nauczania}

Edukacja odgrywa kluczową rolę w kształtowaniu życia młodych Australijczyków i przyczynia się do powstawania demokratycznego i sprawiedliwego społeczeństwa, które dobrze prosperuje, jest spójne oraz różnorodne kulturowo. Australijski Program Nauczania został zatem tak zaprojektowany, aby umożliwić wszystkim młodym Australijczykom możliwość bycia uczniami odnoszącymi sukcesy, pewnymi siebie i kreatywnymi oraz aktywnymi i świadomymi obywatelami. Program ten obejmuje uczniów od nauki w „zerówce” do 10. roku edukacji, ukierunkowuje nauczycieli, rodziców, uczniów i inne osoby w szerszej społeczności na tematy, których należy nauczyć, a także określa jakość uczenia się, jaka jest oczekiwana od młodych ludzi w trakcie ich pobytu w szkole.

Na każdym etapie edukacji, począwszy od klasy zerowej (Foundation Year) ${ }^{1}$ do 10. roku edukacji Australijski Program Nauczania uwzględnia szczegóły wiedzy, umiejętności ucznia i poziom zrozumienia zagadnień z określonej dyscypliny. Można podzielić jego tematykę na osiem obszarów: angielski, matematyka, nauka, zdrowie i wychowanie fizyczne, nauki humanistyczne i społeczne, sztuka, technologie i języki. Cztery ostatnie dziedziny nauki zostały napisane tak, aby obejmowały wiele przedmiotów, odzwierciedlając zwyczaje i praktykę obowiązujące w danej dyscyplinie. W każdym obszarze nauki lub temacie opisy treści określają, czego młodzi ludzie się nauczą, a standardy osiągnięć strukturalizują stopień zrozumienia tematu oraz zakres wiedzy i umiejętności oczekiwanych od uczniów pod koniec każdego roku nauki lub w danym przedziale wiekowym. W ten sposób program określa podstawy pod przyszłą naukę uczniów, ich rozwój oraz aktywne uczestnictwo w australijskiej społeczności.

Australijski Program Nauczania wskazuje na oczekiwania co do zakresu nauki młodych Australijczyków, bez względu na to, czy mieszkają oni w samej Australii czy też na jej obrzeżach. Przesłankami przyświecającymi wprowadzeniu Australijskiego Programu Nauczania w życie były poprawa jakości, równości i przejrzystości australijskiego systemu edukacji (quality, equity and transparency). Poszczególne terminy oznaczają:

- jakość - australijski program nauczania zapewnić ma edukację na światowym poziomie, z uwzględnieniem takich jej aspektów, jak:wiedza, zrozumienie i umiejętności potrzebne do życia i pracy w XXI wieku.

- słuszność/sprawiedliwość - Australijski Program Nauczania zapewnić ma jasne, wspólne zrozumienie tego, czego należy uczyć młodych ludzi i jakiej jakości nauki się od nich oczekuje, bez względu na okoliczności, rodzaj szkoły czy jej lokalizację.

1 W zależności od stanu lub terytorium nazywany: Kindergarten, Pre-Primary, Preparatory, Reception, Transition. 
- $\quad$ przejrzystość - wszystkie szczegóły programu nauczania na wszystkich poziomach edukacji są powszechnie dostępne do wiadomości oraz opisane w sposób możliwie dokładny i klarowny.

Przyjęcie Australijskiego Programu Nauczania w całym kraju pozwoliło na wykorzystanie zbiorowej wiedzy i podjęcie wspólnego wysiłku w dążeniu do celu, oraz z ekonomicznego punktu widzenia - sprawiło znaczne ograniczenie wydatkowania czasu, wysiłku i zasobów.

\section{Cele międzyprzedmiotowe}

Globalna Perspektywa w edukacji obejmuje trzy priorytety nauczania, uwzględnione w Australijskim Programie Nauczania. Są to tzw. priorytety międzyprzedmiotowe, które pełnią funkcję wspomagającą proces uczenia się.

Priorytety zawarte w międzyprzedmiotowym programie nauczania są realizowane wyłącznie w obszarach nauki i nie stanowią samodzielnego przedmiotu nauczania, ponieważ nie istnieją poza obszarami uczenia się. Zamiast tego są one identyfikowane, niezależnie od tego, gdzie zostały opracowane lub zastosowane. Są również uwzględniane wówczas, gdy umożliwiają lepszy i bogatszy proces uczenia się. Mają też swoją siłę i są obecne na różnorodny sposób, w zależności od ich znaczenia dla danego obszaru nauki. Każdy priorytet posiada objaśnienie, które określa powód jego włączenia w życie, i opisuje, w jaki sposób jest traktowany w programie nauczania. Wszystkie zostały opracowane wokół trzech kluczowych zagadnień: historia i kultura Aborygenów i mieszkańców wysp w cieśninie Torresa; Azja i zaangażowanie Australii na terenie Azji oraz zrównoważony rozwój. W ich ramach są tworzone i realizowane pomysły bądź projekty, których zadaniem jest przeprowadzenie działań odpowiadających tematycznie wskazanym powyżej obszarom nauki. Porządkowanie (dopasowanie do danego przedmiotu) pomysłów i projektów jest ujęte w takim obszarze (przedmiocie), który jak najbardziej wpasowuje się w treści zawarte w założeniach organizacyjnych. Jednak sama idea może czerpać treści z więcej niż jednego obszaru nauki. Podobnie pojedynczy opis treści lub opracowanie zakresu tematycznego może obejmować jeden lub więcej pomysłów organizacyjnych w ramach jednego lub większej liczby priorytetów.

Australijski Program Nauczania oraz uwzględnione w nim priorytety międzyprzedmiotowe mają na celu zaspokojenie potrzeb uczniów poprzez dostarczanie im odpowiedniego, współczesnego i angażującego programu, który opiera się na celach edukacyjnych Deklaracji Melbournskiej.

\section{Przykłady działań edukacyjnych realizowanych w australijskich szkołach, uwzględniające cele edukacji globalnej}

Projekt edukacyjny pt. Global Maths („Globalna matematyka”) został zrealizowany w Auburn Girls High School w Nowej Południowej Walii. Jego uczestnikami było 
30 uczennic na ósmym roku edukacji. Został on przeprowadzony w ramach międzyprzedmiotowych celów na lekcjach $\mathrm{z}$ matematyki. Impulsem do powstania tego projektu była dotacja, którą Matematyczne Stowarzyszenie Nowej Południowej Walii (The Mathematical Association of New South Wales) otrzymało z Globalnego Projektu Edukacyjnego Nowa Południowa Walia (Global Education Project New South Wales). Został on przyznany na promocję umiejętności liczenia w kontekście edukacji globalnej, w punkcie „Tożsamość i różnorodność kulturowa”. Dyrektor szkoły uzyskał ogólnoszkolną międzyprzedmiotową (międzywydziałową ${ }^{2}$ ) pomoc w planowaniu i wdrażaniu trzydniowego programu nauczania międzykulturowego opartego na założeniach The Amazing Race ${ }^{3}$.

Uczniowie zostali podzieleni na cztery grupy, aby zbadać wybrany kraj z regionu Azji i Pacyfiku, wykonując szereg zadań w ścisłych ramach czasowych. Obejmowały one następujące czynności:

1. przygotowanie prezentacji na temat wybranego kraju (matematyka i geografia), z uwzględnieniem: faktów i charakterystyki, w porównaniu do Australii, języków w nich używanych, z kilkoma kluczowymi pozdrowieniami, walutą, i jej przelicznikiem na dolary australijskie, aspektów demograficznych, populacyjnych, rozkładu obszaru miejskiego/wiejskiego, śmiertelności i wskaźnika urodzeń oaz przewidywanej populacji na rok 2050, mapy kraju z prowincjami i stolicami, rzekami, górami itp., opisy pogody, szczegółów kulturowych i kwestii praw człowieka, informacji o transporcie - rodzaje i wskaźniki wykorzystania;

2. jak się komunikować? (nauka i technologia). Zbieranie informacji na temat wykorzystania technologii (kuchenki mikrofalowe, telefony komórkowe, internet, komputery) oraz ich wpływu na środowisko;

3. co weźmiesz? (geografia i matematyka). Zaplanowanie tego, jaki bagaż można zabrać ze sobą do innego kraju, uwzględniając jego wagę, jeśli istnieją ograniczenia linii lotniczej;

4. co będziesz jadł? (zdrowie, matematyka). Badanie lokalnych kuchni; przygotowanie prostego przepisu dla siedmiu osób w ramach wcześniej zaplanowanego budżetu;

5. gdzie pójdziesz? (geografia, matematyka). Zbadanie najważniejszych atrakcji w stolicy (np. miejsca dziedzictwa, miejsca kultu religijnego lub innego kultu

$2 \mathrm{~W}$ ramach tego projektu jest nabywana i utrwalana wiedza z kilku przedmiotów.

3 The Amazing Race są to zajęcia uczniów w klasie, w których uczniowie siedzą przy stoliku 4-6 uczniów (w zależności od wielkości sali). Tylko dwóch jednocześnie może opuścić swoją grupę w dowolnym momencie. Wokół pomieszczenia znajduje się kilka stanowisk z zadaniami. Uczniowie pracują w grupach, aby odpowiedzieć na wszystkie pytania w swoim arkuszu. Robią to, odwiedzając stacje i przekazując informacje do grupy, aby umożliwić im wypracowanie odpowiedzi. 
itp.); tworzenie mapy pokazującej lokalizację tych miejsc i odległości, jakie trzeba przebyć, aby je zobaczyć;

6. planowanie podróży (angielski, geografia, matematyka). Uczniowie przygotowali szczegółowy plan przedwyjazdowy i plan podróży na trzydniowy wyjazd do wyznaczonego kraju, wyjeżdżając z Sydney. Szczegółowy plan: wymagania wizowe, wymagania dotyczące bagażu, niebezpieczeństwa w podróży do danego kraju, plan podróży, oś czasu oparta na miejscach do odwiedzenia, sposobie transportu i odległościach (średnia prędkość, różnice czasowe, czas spędzony na podróży), budżet na podróże, zakwaterowanie, wyżywienie, opłaty za wyminę walut.

Ewaluacja przed i po wskazywała na lepsze zrozumienie koncepcji numerycznych, przestrzennych, pomiarowych i statystycznych oraz umiejętności zastosowania ich w rozwiązywaniu problemów. Oceny nauczycieli były pozytywne. Uczniowie lubili pracować w zespołach międzywydziałowych i zdobywać wiedzę na temat włączania globalnej perspektywy do matematyki i własnych obszarów uczenia się.

Kolejny projekt edukacyjny pt. Walking for water („Chodzić po wodę”) zrealizowany został w St. Monica’s College w Epping w stanie Victoria. Jego uczestnikami było 50 uczniów $\mathrm{z}$ 10. roku edukacji. prowadzony był w ramach międzyprzedmiotowych celów na lekcjach $\mathrm{z}$ matematyki. Impulsem do powstania tego projektu była chęć zaangażowania uczniów w problematykę sprawiedliwości społecznej. Nauczyciele chcieli uczulić uczniów na nierówności społeczne na przykładzie ograniczeń w dostępie do wody i urządzeń sanitarnych wśród ludzi żyjących w krajach rozwijających się. Dodatkowo zachęcał ich do myślenia o zużyciu wody i do podjęcia działań w celu ewentualnych zmian. Projekt ten bazował na informacjach uzyskanych z projektu wodnego Caritas w Tanzanii.

Uczniowie wyliczyli własne zużycie wody i porównali ją do typowej ilości wody używanej przez ludzi w wielu krajach w Afryce subsaharyjskiej. Biorący udział w projekcie próbowali nosić wodę przez 10 minut, a następnie obliczyli, ile czasu zajmie im pokonanie z nią sześciu kilometrów. Zostali następnie zapoznani z historią projektu Tanzania (Caritas Australia, Improving water, sanitation and community life in Tanzania), a następnie zbadali najlepsze możliwe miejsca punktów dostępowych do wody i najbardziej efektywny kształt zbiornika, wykorzystując przy tym umiejętności pomiarowe - mierzenie powierzchni, powierzchni całkowitej, objętości i pojemności.

Jednym z pierwszych zauważalnych efektów tych zajęć było duże zaangażowanie uczniów w zajęcia, nawet tych najbardziej nieśmiałych lub niezainteresowanych przedmiotem. Uczniowie starali się opracować najlepsze możliwe rozwiązania. Pytania, których by nie zadali w przeszłości, stały się ważnym wyzwaniem, z którym musieli się zmierzyć ze względu na mieszkańców wioski w Tanzanii. Uczniowie poradzili sobie zarówno z zadaniem, jak i lepiej zrozumieli, jakie znaczenie ma woda, a wielu z nich zauważyło, że zdecydowanie bardziej świadomie starają się 
ją oszczędzać. Ponadto uczniowie rozwinęli empatię w stosunku do tych, którzy mają o wiele mniej szczęścia niż oni. Kilku uczniów z tej grupy dołączyło później do szkolnej grupy sprawiedliwości społecznej.

Bridging cultures („Pomost kultur”) to tytuł projektu edukacyjnego zrealizowanego w Macarthur Anglican School, w miejscowości Cobbitty, w stanie Nowa Południowa Walia. Jego uczestnikami było 50 uczniów z 9-12. roku edukacji. Projekt był realizowany w ramach międzyprzedmiotowych celów na lekcjach języka indonezyjskiego. Nauczyciele dążyli do zwiększenia wiedzy i umiejętności językowych oraz poprawy możliwości zrozumienia międzykulturowego wśród swoich uczniów. Zajęcia zostały zrealizowane w oparciu o założenia projektu pod nazwą BRIDGE („Budowanie relacji poprzez dialog międzykulturowy i rosnące zaangażowanie"), w ramach podjętej współpracy z Indonezyjską szkołą Madrasah Tsanawiyah Negeri $3 \mathrm{w}$ Jakarcie $\left(\mathrm{MTsN}_{3}\right)$. Motywacją do podjęcia działań w ramach projektu było przekonanie, że celem nauki języków jest budowanie relacji np. w turystyce lub biznesie. Program BRIDGE umożliwił rozwój relacji z indonezyjskimi nauczycielami i uczniami. Takie wsparcie w procesie nauki języka przełożyło się na rozwijanie takich wartości, jak: szacunek, gościnność, współczucie i empatia.

Początek programu datowany jest na rok 2010 i wiąże się z wizytą studyjną dwóch nauczycieli z MTsN 3 w szkole Macarthura, której celem była promocja współpracy online. Podczas pobytu nauczyciele z MTsN 3 stali się cennymi członkami szkolnej społeczności. Byli pytani przez uczniów o takie tematy, jak: życie rodzinne, szkolne, zdrowie i kwestie środowiskowe. Ciekawym doświadczeniem była ich wizyta w klasie uczniów z 11. roku edukacji, na zajęciach z religii. Otwarta dyskusja i wymiana doświadczeń poszerzyły zrozumienie przez uczniów problematyki islamu we współczesnym kontekście indonezyjskim. Uczniowie z 9. roku edukacji wzięli udział w serii lekcji za pośrednictwem Skype’a z uczniami w dwujęzycznej „klasie kangura” z MTsN 3. Uczniowie pytali się nawzajem o życie rodzinne i społeczne w Indonezji i Australii, byli mile zaskoczeni wieloma podobieństwami w ich życiu.

Od tego czasu stosunki między obiema szkołami nabrały rozpędu dzięki podpisaniu Protokołu Zrozumienia (Memorandum of Understanding), sesji Skype'a, współpracy opartej na ICT (Kirschner 2016) i dodatkowych wizytach w szkołach pracowników i studentów. Podczas każdej wizyty powstawało wiele silnych przyjaźni, a obie społeczności szkolne skorzystały z możliwości okazania obopólnej gościnności.

Współpraca online nadal rośnie dzięki takim inicjatywom, jak np. międzyszkolny konkurs mowy. Każda szkoła wybrała trzech finalistów konkursu, którzy wystąpili w finale na żywo za pośrednictwem Skype'a. Nauczyciele z MTsN 3 wybrali najlepszego indonezyjskiego mówcę - Macarthura, zaś personel Macarthura wybrał najlepszego anglojęzycznego mówcę z MTsN 3. Podczas dwudniowej wizyty w MTsN 3 uczniowie i pracownicy Macarthur byli szczególnie poruszeni podniesieniem australijskiej flagi i śpiewem hymnu podczas uroczystości powitalnej. 
Międzykulturowa i językowa nauka oraz współpraca w Macarthur kończy się na 12. roku edukacji dziennikiem edukacyjnym dokumentującym metakognitywne porozumienia i refleksje na temat tożsamości osobistej, a także opisującym obszary zainteresowań uczniów, takie jak środowisko, religia i problemy młodzieży. Dziennik ten ukazuje zdolności uczniów do rozróżniania wzajemnych powiązań języka i kultury, np. poprzez porównanie idiomów, znaczenia dialektu, a także wykorzystanie pasywnej konstrukcji (passive construction) do odwrócenia uwagi od tematu. Te dzienniki są dostępne do użytku dla innych uczniów.

Projekt edukacyjny pt. Making a multicultural school („Tworzenie wielokulturowej szkoły") został zrealizowany w Glen Waverley Primary School, w stanie Victoria. Jego uczestnikami było 500 uczniów z 6. roku edukacji. Jako że w Glen Waverley Primary School uczą się uczniowie z 35 różnych krajów, głównie ze Sri Lanki, Indii, Chin i Korei, istnieje w niej duża mobilność, ponieważ wiele rodzin jest tzw. migrantami biznesowymi. Szkoła ściśle współpracowała z Globalnym Projektem Edukacyjnym (The Global Education), aby opracować całościowe podejście do wielokulturowych i globalnych perspektyw obywatelskich w całym programie nauczania.

Szkoła, witając nowe rodziny, omawia z nimi oczekiwania, aby zapewnić wszystkim rodzinom poczucie komfortu oraz zminimalizować jakiekolwiek problemy z zadomowieniem się. Rodziny są oprowadzane po szkole z tłumaczami (jeśli to możliwe), otrzymują również pakiet informatorów i map oraz zaproszenie na powitalny podwieczorek. Tam, gdzie jest to konieczne, rodzice zapisywani są na lekcje języka angielskiego i są kontaktowani z organizacjami pomocy społecznej. $\mathrm{W}$ ciągu miesiąca od przybycia $\mathrm{z}$ nowymi rodzinami kontaktuje się kierownik ds. dobrego samopoczucia studenta lub dyrektor szkoły i nauczyciel. Rodziny maja również spotkania z innymi rodzicami, których dzieci są na tym samym poziomie nauczania bądź w tym samym wieku.

Wokół szkoły umieszczone są flagi i znaki powitalne w różnych językach. Zespoły szkolne zajmują się organizacją przedstawień, tworzą chór śpiewający w języku chińskim, biorą udział w lekcjach tańca indyjskiego, lankijskiego i greckiego oraz grają na tradycyjnych chińskich instrumentach, np. na cytrze. Dzieci w szkole witane są w różnych językach. Organizowane są ważne festiwale kulturalne, takie jak Chiński Nowy Rok i Diwali (hinduistyczne święto światła).

Podczas Tygodnia Różnorodności Kulturowej przewodniczący Komisji Wielokulturowej Wiktorii (Victorian Multicultural Commission) zaprosił każde dziecko, aby zwróciło się do sąsiada i przywitało się w jego ojczystym językiem. Jeden z uczestników powitał wszystkich w języku afrykańskim: „Moimi myślami pozdrawiam was; Moimi słowami was pozdrawiam; sercem moim pozdrawiam; Nie mam nic w zanadrzu".

Członkowie społeczności zapewnili pracownikom profesjonalne szkolenie obejmujące informacje o pochodzeniu uczniów i opisujące specyfikę ich krajów 
pochodzenia, wartości rodzinne i wzajemne oczekiwania. Wszystkie osoby związane ze szkołą są aktywnie zaangażowane ww wspieranie zajęć edukacyjnych.

Nowi uczniowie są skontrowani w klasie z „kumplem”, który będzie się nimi opiekował. Nauczyciele w swoim programie nauczania uwzględniają treści dotyczące doświadczeń życia w różnych krajach. Szkoła podjęła się szerokiej gamy inicjatyw o charakterze wielokulturowym i globalnym, w tym pracy z ambasadorami UNICEF-u i Childfund Connect, aby nawiązać cyfrowe połączenia z dziećmi w Wietnamie, Timorze Wschodnim, Laosie i Sri Lance.

Na każdym poziomie edukacji uczniowie są zaangażowani w działania skoncentrowane na zjawisku globalizacji, a nauczyciele dbają o poczucie odpowiedzialności społecznej i o aktywne obywatelstwo swoich uczniów (active citizenship). Zachęca się też wszystkich do stosowania globalnego spojrzenia w trakcie pracy w szkole, umożliwia się im zrozumienie tego, że mają udział w dokonywaniu pozytywnych zmian we własnej społeczności i na świecie.

W 2012 roku szkoła została doceniona za wyjątkowe wysiłki w pracy na rzecz wielokulturowej i szerszej społeczności przez wyróżnienie Excellence in Multiculturalism Award. Jest to tzw. nagroda za „doskonałość”, którą przyznaje się wybitnym osobom i organizacjom poświęcającym się wybranej dziedzinie i zaangażowanym we wspieranie różnorodności kulturowej, co ma pozytywny wpływ na społeczność lokalną.

Projekt edukacyjny pt. World Wise School („Światowa mądra szkoła”) zrealizowany został w Ashburton Primary School, w stanie Victoria. Jego uczestnikami było 489 uczniów z 6. roku edukacji. Po profesjonalnej nauczycielskiej sesji edukacyjnej, realizowanej w ramach projektu Global Education Project (2008), pracownicy postanowili zachęcić uczniów do poszerzenia swoich światopoglądów, aby stać się bardziej aktywnymi obywatelami świata.

Program World Wise opiera się na założeniach Global Education Framework. Podkreśla jedność i współzależność społeczeństwa ludzkiego, uznanie różnorodności kulturowej, praw człowieka, budowanie pokoju i działania na rzecz zrównoważonej przyszłości w różnych czasach i miejscach. Aktywności realizowane w każdym semestrze koncentrują się na innym kontynencie. Aby uczniowie mogli w pełni nabywać wiedzę, przygotowano im specjalną salę z mapami i artefaktami z całego świata. Zrobiono im specjalne paszporty do „odwiedzanych” i omawianych krajów. Zapiski z każdej „podróży” były przechowywane w poszczególnych dziennikach. Uczniowie poznawali różnorodność kulturową za pomocą języka, historii, geografii, zwyczajów i żywności.

Prelegenci z organizacji wspierających globalną edukację angażowali uczniów w rzeczywiste sytuacje, jakich mogliby oni doświadczać w obcych krajach. Uczniowie zaczęli szerzej myśleć o otaczającym ich świecie i planować podjęcie działań na rzecz zmian. Przykładowo uczniowie z 5. roku edukacji gotowali jedzenie, aby zebrać ponad 500 dolarów na wsparcie osieroconych orangutanów na Borneo. Cała szkoła stworzyła przedmioty z materiałów pochodzących 
z recyklingu, aby sprzedać i zebrać fundusze na kampanię Make Poverty History. Uczniowie $\mathrm{z}$ „zerówki” przygotowali naszyjniki z makaronu, z 1. roku edukacji malowali kamienie życzeń, $\mathrm{z}$ 2. roku wykonali naszyjniki z pereł drewnianych, z 3 . i 4. roku wykonali bransoletki przyjaźni, zaś uczniowie z 5. i 6. roku wykonywali lalki i modele. Dzięki takiej aktywności uczniowie rozwinęli globalny sposób myślenia, próbując zrozumieć różnorodność życia ludzi w innych krajach. Nauczyli się brać odpowiedzialność za swoje działania, szanować i cenić wielokulturowość oraz postrzegać siebie jako globalnych obywateli, którzy mogą przyczynić się do pokojowego, sprawiedliwego i zrównoważonego świata.

\section{Australijska edukacja a edukacja globalna: podsumowanie}

Zasadniczym celem edukacji globalnej na australijskim kontynencie jest rozwój tzw. globalnych obywateli (global citizens). Cel ten jest realizowany poprzez promowanie działań i postaw sprzyjających otwartości umysłu i gotowości do podejmowania działań na rzecz zmian, szanowania i doceniania różnorodności oraz promowania aktywnego udziału w rozwoju pokojowego, sprawiedliwego i zrównoważonego świata.

Wspomniane wyżej działania są realizowane w oparciu o założenia Deklaracji Melbournskiej, określającej cele edukacyjne młodych Australijczyków. Deklaracja za najważniejsze zadanie uznaje promocję równości i doskonałość, wspieranie rozwoju odnoszących sukcesy uczniów, pewnych siebie i kreatywnych jednostek, aktywnych oraz świadomych obywateli. Cele te osiągane mają być poprzez: rozwijanie silniejszych form współpracy, wspieranie wysokiej jakości nauczania i przywództwa w szkole, wzmocnienie edukacji wczesnoszkolnej, poprawę rozwoju uczniów w średnim wieku, wspieranie uczniów ze starszych lat nauki, w tym przy ich przejściu na wyższy poziom edukacji, promowanie światowej klasy programu nauczania i oceniania, poprawa wyników edukacyjnych wśród młodzieży rdzennych Australijczyków (Aborygenów) i znajdujących się w niekorzystnej sytuacji młodych Australijczyków, zwłaszcza tych z niskiego poziomu społeczno-ekonomicznego oraz wzmocnienie odpowiedzialności i przejrzystości działań edukacyjnych (Melbourne Declaration on Education Goals for Young Australians, 2008).

Tym samym edukacja globalna jest ważnym elementem składowym Australijskiego Programu Nauczania oraz międzyprzedmiotowych celów edukacyjnych, uwzględnianych na każdym roku edukacji. Same działania mają zaś wymiar krajowy, regionalny i globalny, co przekłada się na wzbogacenie programu nauczania poprzez opracowanie interesujących i skoncentrowanych na globalne działanie treści. Tematyka szkoleniowa ma ścisły związek czasowy z edukacją międzyprzedmiotową, umożliwia to rozwój wiedzy, lepsze zrozumienie tematu i nabycie umiejętności związanych z omawianymi zagadnieniami.

Edukacja globalna skupia się na nieograniczonym lokalnie kształceniu, które umożliwia uczniom poznanie świata, rozwijanie wartości wokół pozytywnego postrzegania siebie, docenienie różnorodności kulturowej, wzrost poczucia sprawiedliwości społecznej, rozumienie praw człowieka oraz budowanie trwałej przyszłości. 
Tabela 1. Australijskie priorytety międzyprzedmiotowe w nawiązaniu do Australijskiego Programu Nauczania

\begin{tabular}{|c|c|c|}
\hline $\begin{array}{c}\text { Priorytety Australijskiego } \\
\text { Programu Nauczania oraz } \\
\text { priorytety międzyprzedmiotowe }\end{array}$ & $\begin{array}{l}\text { Powiązane } \\
\text { akcenty zwią- } \\
\text { zane z edukacją } \\
\text { globalną }\end{array}$ & Zawartość \\
\hline $\begin{array}{l}\text { Historia i kultura Aborygenów } \\
\text { i mieszkańców wysp w cieśninie } \\
\text { Torresa }\end{array}$ & $\begin{array}{l}\text { Współzależność } \\
\text { i globalizacja; } \\
\text { Tożsamość } \\
\text { i różnorodność } \\
\text { kulturowa; } \\
\text { Sprawiedliwość } \\
\text { społeczna i prawa } \\
\text { człowieka }\end{array}$ & $\begin{array}{l}\text { Grupy mniejszości na } \\
\text { całym świecie, ich specjalne } \\
\text { powiązania i znajomość } \\
\text { ich specyfiki w społeczeń- } \\
\text { stwach, z uwzględnieniem } \\
\text { historycznego, społecznego } \\
\text { i politycznego punktu } \\
\text { odniesienia }\end{array}$ \\
\hline $\begin{array}{l}\text { Azja i zaangażowanie Australii } \\
\text { w Azję }\end{array}$ & $\begin{array}{l}\text { Tożsamość } \\
\text { i różnorodność } \\
\text { kulturowa; } \\
\text { Sprawiedliwość } \\
\text { społeczna i prawa } \\
\text { człowieka }\end{array}$ & $\begin{array}{l}\text { Różnorodność tradycji, } \\
\text { kultur, systemów wierzeń } \\
\text { i religii ludzi z krajów } \\
\text { azjatyckich; } \\
\text { Sprawiedliwe i pokojowe } \\
\text { stosunki z krajami na ca- } \\
\text { łym świecie; } \\
\text { Skuteczne obywatelstwo } \\
\text { regionalne i globalne }\end{array}$ \\
\hline Zrównoważony rozwój & $\begin{array}{l}\text { Zrównoważona } \\
\text { przyszłość }\end{array}$ & $\begin{array}{l}\text { Równoważenie społecz- } \\
\text { nych, politycznych, ekono- } \\
\text { micznych i środowiskowych } \\
\text { aspektów życia na Ziemi }\end{array}$ \\
\hline
\end{tabular}

Źródło: https://www.globaleducation.edu.au/teaching-and-learning/australian-curriculum.html

Podobnie jak Australijski Program Nauczania, edukacja globalna ma charakter interdyscyplinarny. Nauczyciele mają swobodę w wyborze sposobów, w jaki zaprezentują nowe pojęcia i wytłumaczą zachodzące w świecie procesy. Sami decydują o tym, jak stopniowo mają pogłębiać zrozumienie omawianych zagadnień, tak aby zwiększyć zaangażowanie w zdobywanie wiedzy i ułatwić uczniom naukę. Umiejętności nabyte podczas uczestnictwa w edukacji globalnej, poprzez podobieństwo do tych będących efektem realizacji Australijskiego Programu Nauczania, stwarzają szanse uczniom, teraz i przez całe życie, na bycie osobami zdolnymi 
do działania w złożonym, bogatym w informacje, zglobalizowanym świecie. Do szczególnie istotnych umiejętności zaliczyć można: krytyczne i twórcze myślenie, zachowanie etyczne, kompetencje osobiste i społeczne oraz zrozumienie międzykulturowe. Opierają się one na relacjach z osobami z innych kultur, uwzględniają ich sposób myślenia, działania i zachowania się.

\section{Bibliografia}

Ashburton Primary School, dostępny na: http://ashburtonps.vic.edu.au (otwarto: 15.10.2018).

Asia Education Foundation (AEF), BRIDGE (School partnerships, Building Relationships through Intercultural Dialogue and Growing Engagement), dostępny na: http://www.asiaeducation.edu.au/programmes/school-partnerships (otwarto: 15.10.2018).

Auburn Girls High School, dostępny na: http://www.auburng-h.nsw.edu.au (otwarto: 15.10.2018).

Australian Curriculum, About the Australian Curriculum, dostępny na: https:// www.australiancurriculum.edu.au/about-the-australian-curriculum (otwarto: 15.10.2018).

Australian Curriculum Assessment and Reporting Authority (ACARA), Crosscurriculum priorities, dostępny na: https://www.acara.edu.au/curriculum/cross-curriculum-priorities (otwarto: 15.10.2018).

Australian Curriculum, Assessment and Reporting Authority (ACARA), English as an Additional Language or Dialect Teacher Resource, dostępny na: http://docs. acara.edu.au/resources/EALD_Overview_and_Advice_revised_February_2014. pdf (otwarto: 15.10.2018).

Australian Curriculum, Cross-curriculum priorities, dostępny na: https://www. australiancurriculum.edu.au/f-10-curriculum/cross-curriculum-priorities (otwarto: 15.10.2018).

Bińczak P. (2013). Edukacja globalna - klucz do zrozumienia i akceptacji. „Edukacja i Dialog", nr 9/10, s. 66-69.

Caritas Australia, Improving water, sanitation and community life in Tanzania, dostępny na: http://www.caritas.org.au/learn/programs/africa---tanzania-integrated-community-development-program (otwarto: 15.10.2018).

Caritas, Projekt Tanzania (Tanzania project), dostępny na: https://www.caritas. org.au/learn/programs/africa---tanzania-integrated-community-development-program (otwarto: 15.10.2018).

ChildFund Australia, dostępny na: https://www.childfund.org.au/about-us (otwarto: 15.10.2018).

Gadzinowska D. (2008). Jak mówić o większości świata: jak rzetelnie informować o krajach globalnego Południa? Warszawa: Instytut Globalnej Odpowiedzialności. 
Gadzinowska D., Lipska-Badoti G., Wojtalik M. (2012). Jak mówić o większości świata: rzetelna edukacja o krajach globalnego Południa. Warszawa: Polska Akcja Humanitarna.

Global Education Network Europe (2009). Edukacja globalna w Polsce Europejski proces partnerskiego przegladu edukacji globalnej. Krajowy raport na temat edukacji globalnej $w$ Polsce. Warszawa.

Global Education, Teacher resources to encourage a global perspective across the curriculum, School case studies, dostępny na: http://www.globaleducation.edu. au/teaching-and-learning/school-case-studies.html (otwarto: 15.10.2018).

Global Education, Teaching activities, Delivering water, dostępny na: http://www. globaleducation.edu.au/teaching-activity/delivering-water-9-10.html (otwarto: 15.10.2018).

Global Perspectives: A framework for global education in Australian schools (2008), Commonwealth of Australia, dostępny na: http://www.globaleducation.edu.au/ verve/_resources/GPS_web.pdf (otwarto: 15.10.2018).

Hechmann R., Bodzan M. (2014). Pomoc humanitarna: materiały z edukacji globalnej. Warszawa: Polska Akcja Humanitarna.

Horton A., Klus-Stańska D. (1994). Kulturowe prawa dzieci z mniejszości narodowych (na przykładzie wielojęzycznej szkoły w Birmingham). „Nowa Szkoła”, nr 3, s. 169-172.

Karpińska A. (2003). Edukacyjne problemy czasu globalizacji w dialogu i perspektywie. Białystok: Trans Humana.

Kędzierska-Grasiewicz M. (2001). Humanitaryzm: scenariusze zajęć do edukacji humanitarnej. Warszawa: Fundacja Polska Akcja Humanitarna.

Kirschner P. A. (2016). ICT-based Collaborative Learning and Innovative Pedagogy, dostępny na: https://3starlearningexperiences.wordpress.com/2016/07/19/ict-based-collaborative-learning-and-innovative-pedagogy (otwarto: 15.10.2018).

Kołodko G. (2001). Moja globalizacja, czyli dookoła świata i z powrotem, Toruń: Dom Organizatora.

Kucińska J. (2009). MEN [Ministerstwo Edukacji Narodowej] wspiera: edukacja globalna w szkołach. „Polski w Praktyce”, nr 1, s. 38-39.

Łomny Z. (1996). Człowiek i edukacja wobec przemian globalnych. Radom: ITE.

Łomny Z. (1998). W intencji przetrwania i rozwoju: kultura i edukacja - o wspólnotową i humanistyczną rewolucję przetrwania i naprawę świata. Warszawa: Elipsa.

Macarthur Anglican School, dostępny na: http://www.macarthur.nsw.edu.au (otwarto: 15.10.2018).

Madrasah Tsanawiyah Negeri 3, dostępny na: http://mtsnegerizjakarta.sch.id (otwarto: 15.10.2018).

Melbourne Declaration on Education Goals for Young Australians (2008), dostępny na: http://www.curriculum.edu.au/verve/_resources/national_declaration_on_ the_educational_goals_for_young_australians.pdf (otwarto: 15.10.2018). 
Noszczyk M. (2011). Globalnie - odpowiedzialnie: materiały dla nauczycieli. Kraków: Fundacja Kultury Chrześcijańskiej Znak.

Nowaczyk M., Świderek G. (red.) (2012). Edukacja globalna dla najmłodszych: pakiet edukacyjny dla szkót podstawowych i przedszkoli. Łódź: Ośrodek Działań Ekologicznych „Źródła”.

Ocetkiewicz I. (2014). Czy w polskiej szkole jest miejsce na edukację globalna?? Próba odpowiedzi z perspektywy nauczycieli gimnazjum. „Hejnał Oświatowy”, nr 5, s. 3-5.

Rosa R. (200o). Edukacja do praw człowieka w społeczeństwie demokratycznym. „Podlaskie Zeszyty Pedagogiczne”, nr 1, s. 11-26.

St. Monica's College, Epping, dostępny na: http://www.stmonicas-epping.com/ about/Pages/default.aspx (otwarto: 15.10.2018).

Szczygieł P., Bartosik Ł., Paluszek A. (2013). Prawo do edukacji: materiały z edukacji globalnej. Warszawa: Polska Akcja Humanitarna.

Szymański W. (2001). Globalizacja: wyzwania i zagrożenia. Warszawa: Difin.

Teoretyczne i praktyczne konteksty edukacji globalnej. (2016). Babicki Z., KuletaHulboj M. (red.). Warszawa: Wydawnictwo Naukowe UKSW.

The Australian Curriculum, dostępny na: http://www.australiancurriculum.edu. au (otwarto: 15.10.2018).

The Global Education, dostępny na: http://www.globaleducation.edu.au (otwarto: 15.10.2018).

The Global Education Project NSW (GEPNSW), dostępny na: http://www.ptc.nsw. edu.au/old/gepnsw/gepnsw-home (otwarto: 15.10.2018).

The Mathematical Association of New South Wales (MANSW), dostępny na: https:// www.mansw.nsw.edu.au (otwarto: 15.10.2018).

Trzaskowski P., Bartosik Ł., Jurkiewicz J., Noszczyk M. (2013). Prawo do Żywności: materiały z edukacji globalnej. Warszawa: Polska Akcja Humanitarna.

Victoria's Multicultural Commission (2012), Victoria's Multicultural Awards for Excellence 2012. Guidelines \& Nomination Form, dostępny na: https://www. multicultural.vic.gov.au/images/stories/documents/1090\%20vmc\%20awards\%20 for\%2oexcellence\%2onominations\%2oform\%2oweb.pdf; link skrócony: http:// bit.ly/fp2019-2-3 (otwarto: 15.10.2018).

Wartości, edukacja, globalizacja. (2002). Kojs W. (red.). Cieszyn: Uniwersytet Śląski.

Wojnar I. (200o). Humanistyczne intencje edukacji. Warszawa: Wydawnictwo Akademickie „Żak”.

Zdanowski J. (2000). Kultury pozaeuropejskie i globalizacja: zderzenia. Warszawa: Elipsa. 


\title{
THE VISION OF GLOBAL EDUCATION ON THE EXAMPLE OF EDUCATIONAL INITIATIVES IN AUSTRALIAN SCHOOLS
}

\begin{abstract}
The article discusses the issue of global education in Australia. It has been characterized by taking into account its purpose and place in the Australian educational program. Its characteristics have been prepared based on the guidelines included in the Australian Curriculum, Melbourne Declaration on Education Goals for Young Australians and cross-curricular objectives. In addition, selected educational activities implemented in Australian schools that meet the assumptions of global education are discussed.
\end{abstract}

Keywords: global education; Australia; sustainable development; education program.

Jarosław Korczak - doktor nauk społecznych w dyscyplinie pedagogika, absolwent Uniwersytetu Warszawskiego oraz Akademii Pedagogiki Specjalnej w Warszawie. Pracuje w Wydziale Nauk Pedagogicznych Akademii Pedagogiki Specjalnej w Warszawie. Główne obszary obecnych zainteresowań badawczych: system i rozwiązania edukacyjne w Australii, losy edukacyjne australijskiej Polonii, edukacja na Pacyfiku. Adres korespondencyjny: ul. Szczęśliwicka 40, 02-353 Warszawa. Adres e-mailowy: korja@02.pl. 